\title{
An appraisal of groundwater quality in selected areas in Warri Metropolis
}

\author{
Ogeleka Doris Fovwe ${ }^{1,}$,, Okpako Solomon ${ }^{1}$, Okieimen Felix Ebhodaghe ${ }^{2}$ \\ ${ }^{1}$ Department of Chemistry, Federal University of Petroleum Resources, Effurun, Delta State \\ ${ }^{2}$ University of Benin, Geo-Environmental and Climate Change Adaptation Research Centre, Benin City
}

Email address:

dorysafam@yahoo.com (Ogeleka D. F.)

\section{To cite this article:}

Ogeleka Doris Fovwe, Okpako Solomon, Okieimen Felix Ebhodaghe. An Appraisal of Groundwater Quality in Selected Areas in Warri Metropolis. Journal of Water Resources and Ocean Science. Vol. 3, No. 5, 2014, pp. 55-60. doi: 10.11648/j.wros.20140305.11

\begin{abstract}
Twenty four (24) groundwater samples were collected from some selected areas in Warri Metropolis, Delta State in the Niger Delta area of Nigeria. The areas covered include: Udu, Ajaminogha, Edjeba, Bendel Estate, Enerhen, Igbudu, Jakpa and Eboh. The quality of these private borehole water samples was assessed using methods recommended for water quality by America Public Health Association. The water samples were analysed for physico-chemical and microbial parameters so as to ascertain their potability. The results revealed that $\mathrm{pH}$ was relatively low in all the waters with values varying from 4.15 to $4.86 \mathrm{pH}$. All the groundwater samples could be termed 'freshwater' as revealed in the total dissolved solids (TDS) and salinity levels, which ranged from $(61.33 \mathrm{mg} / \mathrm{L}$ to $277.0 \mathrm{mg} / \mathrm{L})$ and $(12.55 \mathrm{mg} / \mathrm{L}$ to $82.59 \mathrm{mg} / \mathrm{L})$ respectively. The mean turbidity values varied from 0.11 to 1.17 NTU. The water samples were fairly soft as revealed in the results for total hardness $\left(12-16 \mathrm{mg} \mathrm{CaCO}_{3} / \mathrm{L}\right)$. Total iron, copper and zinc had concentrations levels within the local (Nigerian) and International [World Health Organization (WHO)] standards. Concentrations levels of these metals in the sampled locations were in trace quantity. However, lead, cadmium and chromium were not detected in any of the samples analyzed. It has been known that intake of water with low $\mathrm{pH}$ values could cause some severe health implications including gastrointestinal disorders and ulcers. This assessment was necessitated due to the fact that individuals resort to digging their privately owned boreholes, since the Government public utility water services have failed and do not supply potable or domestic waters to residences in these areas. In this vein, since residents in these areas use the untreated water from such borehole extensively for drinking and major domestic purposes, there may be likely health and environmental implications.
\end{abstract}

Keywords: Water Quality, Potability, Standards, Contamination, Safe Drinking, Parameters

\section{Introduction}

Water is an essential and useful natural resource that is needed by all forms of life for survivor, and without water, there would be no life. Safe water means water that would not harm the person drinking or using it. To be safe, the water must have sufficiently low or no concentrations of harmful contaminants to avoid sickening people who use it. Water may be naturally potable, as is the case with pristine springs, or it may need to be treated in order to be safe. In either instance, the safety of water is assessed with analysis which looks for potentially harmful contaminants while ensuring that certain regulatory standards are complied with [1].

Water contains lots of dissolved chemicals, and since ground water moves through rocks and subsurface soil, it has a lot of opportunity to dissolve substances as it moves. Water is the most abundant substance on earth and an integral part of living tissue (about $25 \%$ of living organisms is made up of solid matter while the remaining $75 \%$ is water). It is also the most valuable resource of man. Water is important to all living things as it covers seventy five $(75 \%)$ of the earth's surface. The oceans contain $97.5 \%$ of the earth's water that is seawater containing about $3.5 \%$ salt $(\mathrm{NaCl})$, which is too salty for humans to drink, the land $2.4 \%$, and the atmosphere holds less than $0.001 \%$. Only one $(1 \%)$ of the earth's water is available for drinking; $2 \%$ is frozen [2].

Safe drinking water is defined as water with microbial, chemical and physical characteristics that meet World Health Organization (WHO) guidelines of national standards on drinking water quality. Water, which is not safe to drink, can carry diseases causing organisms, heavy metals and organic contaminants [3-5]. It is believed that many of the diseases 
associated with water contamination are caused by pathogens. Examples of pathogens are bacteria, viruses, and parasites. Pathogens are considered to be "communicable" because they have the ability to spread from one person to another by way of contaminated water and/or other vectors. The most common diseases spread through water are diarrheal diseases; examples include cholera, typhoid, paratyphoid, salmonella, giardiasis, and cryptosporidiosis. Many pathogens arise from animal and human feaces and from insufficient water supply. People who consume such water could become ill, and there is the risk of death. Unfortunately, even in areas where the water is known to be unsafe, people may still drink it out of desperation or since there are no other alternatives. The lack of potable water is often accompanied by lapses especially in sanitation, such as open sewers and limited garbage collection [6].

Sources of natural water include rainwater, spring water, well water, river water, lake water and seawater. The presence of any contaminant would make water impure and fall short of its characteristics quality. If the water becomes polluted, it may lose its value economically and aesthetically and can become a threat to human health and to the survival of aquatic organisms living in it and the wildlife that depends on it. Water pollution comes from two main sources: natural processes (rainwater runoffs, tornadoes, tsunamis, agricultural, land and mining operations) and anthropogenic activities (wastewater, sewage effluent, petroleum contamination).

However, the following activities may cause harmful chemicals / substances to enter surface water and likely percolate groundwater supplies.

1 leakage from waste disposal, treatment, or storage underground sites / tanks.

2 discharges from factories, industrial sites or sewage treatment facilities.

3 leaching from aerial or land application of pesticides and fertilizers on farms or fields.

4 accidental chemical / oil spills.

5 improper disposal of household wastes such as cleaning fluids, paint and motor oil.

6 seepage from septic tanks or suck away pits.

In Nigeria, the Government public utility water supply no longer functions and as such individuals resort to digging their own privately owned boreholes. Most groundwater borehole owners do not disinfect or treat the water from their supplies. The water from these sources is used untreated $[7,8]$.

The quality of drinking water can be determined by its appearance, taste, and odour. Water quality parameters for which standards are established and determined are classified into two main groups: physico-chemical and bacteriological properties. Physico-chemical properties include: Organoleptic (odour, colour, taste, smell), physico-chemical ( $\mathrm{pH}$, temperature, total dissolved solids (TDS), total suspended solids (TSS), total solids (TS), salinity as chloride, bicarbonate, alkalinity, sulphate, nitrate, conductivity, turbidity, total hardness and so on), inorganics (light and heavy metals - calcium, magnesium, iron, lead, chromium, cadmium, copper and so on), organics (pesticides, oil \& grease, total hydrocarbon content (THC), polyaromatic hydrocarbon $(\mathrm{PAH})$, polychlorinated biphenyl (PCB), total petroleum hydrocarbon (TPH) and so on), gross organics [biochemical oxygen demand (BOD), dissolved oxygen (DO), chemical oxygen demand (COD), total organic content (TOC), permanganate value (PV)]. Bacteriological properties include: total coliform, E. coli, Clostruidum perfringes and so on.

The most common standards used to assess water quality related to drinking water, safety of human contact and the health of ecosystems include: World Health Organisation (WHO), Department of Petroleum Resources (DPR), Federal Ministry of Environment (FME), Nigerian Industrial Standards (NIS), United State Environmental Protection Agency (USEPA). However, standard established by WHO is the most commonly referred to.

The aim of this study was to evaluate the physico-chemical and biological characteristics of different borehole water in some selected areas in Warri Metropolis in the Niger Delta area of Nigeria. This is with a view to ascertaining their potability since the water is not treated and are used extensively for drinking and major domestic purposes.

\section{Materials and Methods}

\subsection{Sampling Location}

Warri is located in Delta State, which is in the Niger Delta ecological zone of Nigeria. The Niger Delta area is a prominent coastal region of the southern part of Nigeria facing the Atlantic Ocean, covering an area of about 70,000 square kilometres and comprising of nine states namely: Abia, Akwa Ibom, Bayelsa, Cross River, Delta, Edo, Imo, Ondo and Rivers states. Warri is in one of the twenty five Local Government Areas (LGAs) of Delta State $[9,10]$. The city is subdivided into Warri South, Warri North and Warri SouthEast. Anthropogenic activities in this region include but not limited to gas flaring, refinery, acid rain/precipitation, burning of wood, fossil fuels, commercial, and so on. To explicitly describe climatic information within a particular area, analysis of long term climate historical data were obtained from the Nigeria Meteorological (NIMET) Centre, Oshodi Lagos with respect to coastal areas comprising Warri, Sapele, Bayelsa and Rivers, between 2000 and 2010. It was noted that the southern part of the country, experienced rainfall between $3000-4500 \mathrm{~mm}$. There is hardly any month without rain in the Niger Delta Coastline. Generally, in the southern part of the country, monthly averages are usually above $300 \mathrm{~mm}$ from June to October but less than $50 \mathrm{~mm}$ from December to March, during which time only about $4 \%$ of the annual rain is recorded. The map of the sampling locations is shown in figure 1 while the sampling points and geographical coordinates are presented in table 1. 
Table 1. Sampling points and geographical coordinates

\begin{tabular}{lll}
\hline Sampling Location & Latitude & Longitude \\
\hline Udu & N050 491 30.31 & E0050 791 64.111 \\
Ajaminogha & N050 521 75.81 & E0050 731 21.311 \\
Edjeba & N050 541 05.21 & E0050 73183.111 \\
Bendel Estate & N050 541 07.81 & E0050 761 42.411 \\
Enerhen & N050 521 73.31 & E0050 771 23.711 \\
Igbudu & N050 51182.91 & E0050 761 46.911 \\
Jakpa & N050 561 60.31 & E0050 751 47.311 \\
Eboh & N050 521 38.11 & E0050 751 37.511 \\
\hline
\end{tabular}

\subsection{Water Sampling}

Water samples were collected in triplicates for physicochemical and heavy metal analysis from twenty four (24) boreholes in Warri Metropolis, Delta State in the Niger Delta area of Nigeria. The areas sampled include: Udu,
Ajaminogha, Edjeba, Bendel Estate, Enerhen, Igbudu, Jakpa and Eboh. The sampling containers were washed with acid and rinsed with detergent and plenty of water to ensure there was no contamination from the sampling containers. Appropriate sampling protocol was duly followed as the first rush of water sample was not taken. Samples were collected after three minutes of constant running of the water. The sample containers were rinsed three times with the water to be sampled before collection. The water samples were stored in $1 \mathrm{~L}$ polyethylene bottles and preserved by cooling at $4^{\circ} \mathrm{C}$ while samples for metals was preserved with 1-2 mL of 1:1 nitric acid (AR) [11]. The nitric acid was added to the water samples for metal analysis because it leads to a drop in $\mathrm{pH}$ therefore the loosely bonded ions can be released for determination.

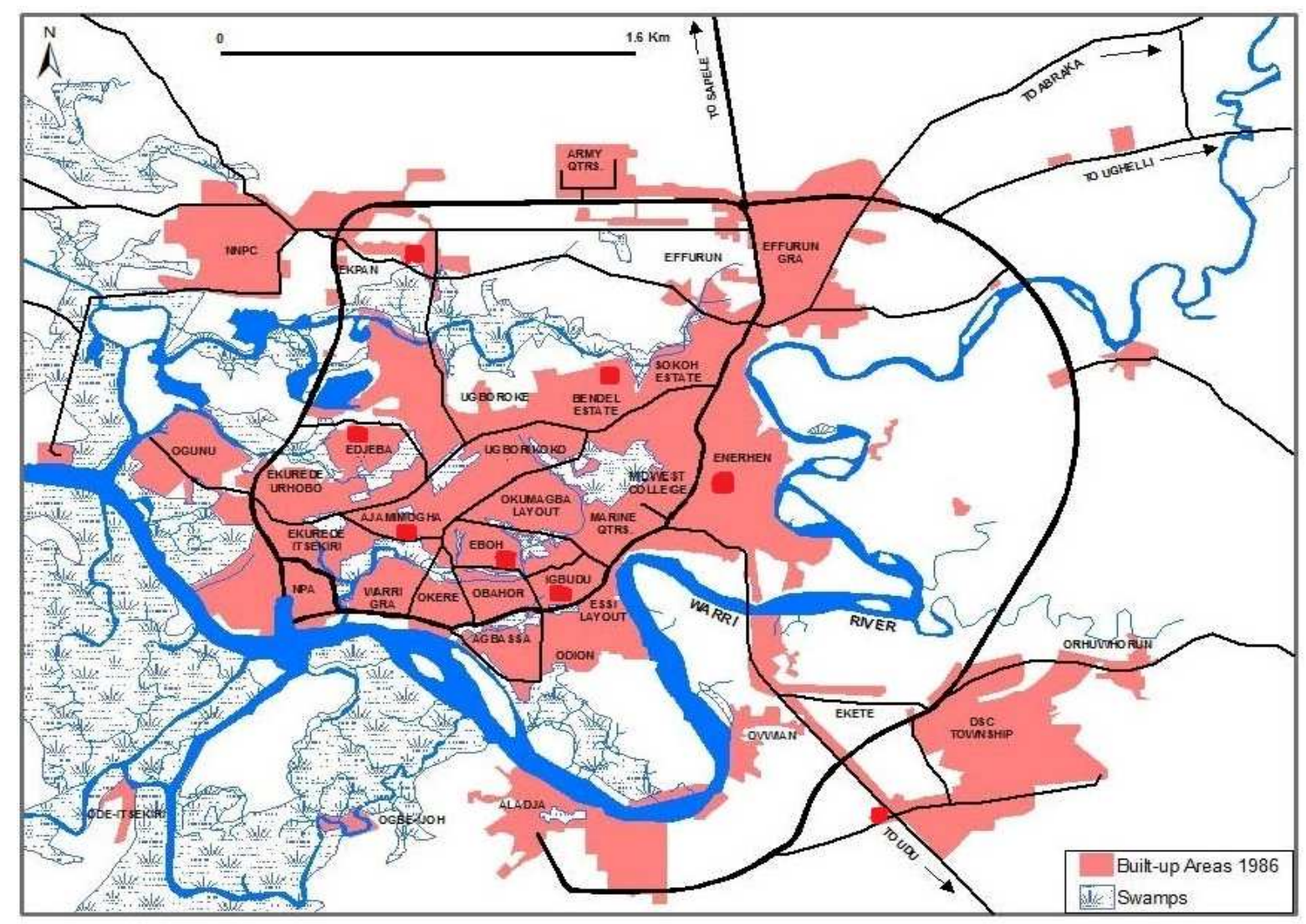

Map drawn by Professor Francis Odemerho, Southern lihinois University, Edw ardsville, USA

Copyright: Unhobo Historical Society 2008

Fig 1. Map of Warri Metropolis showing sampling locations (red)

Table 2. Some indicating parameters determined for this assessment

\begin{tabular}{|c|c|}
\hline Parameters & Analytical Methods \\
\hline $\mathrm{pH}$ & $\mathrm{pH},\left(\mathrm{APHA} 4500 \mathrm{H}^{+},[12]\right.$ \\
\hline Temperature, ${ }^{\circ} \mathrm{C}$ & Thermometer (APHA, 2550-B) \\
\hline Total dissolved solids (TDS), mg/L & TDS (APHA 2540-C) \\
\hline Dissolved oxygen (DO), mg/L & DO (Winkler), (APHA 4500-O-B ) \\
\hline Salinity $\left(\mathrm{Cl}^{-}\right), \mathrm{mg} / \mathrm{L}$ & Mohr's Argentometric method (APHA 4500 Cl-B) \\
\hline Conductivity, $\mu \mathrm{S} / \mathrm{cm}$ & Conductivity (APHA 2510 B) \\
\hline Sulphate, $\mathrm{mg} / \mathrm{L}$ & $\mathrm{SO}_{4}{ }^{2-}$ (Turbidimetric), (APHA $\left.4500-\mathrm{SO}_{4}{ }^{2-}-\mathrm{B}\right)$ \\
\hline Total suspended solids (TSS), mg/L & TSS (APHA 2540-C) \\
\hline Nitrate, $\mathrm{NO}_{3}-\mathrm{N}, \mathrm{mg} / \mathrm{L}$ & APHA 4600- $\mathrm{NO}_{3}-\mathrm{B}$ \\
\hline
\end{tabular}




\subsection{Determination of Metals in Water Samples}

Water samples were digested using concentrated nitric acid (AR). The samples were mixed and $50 \mathrm{~mL}$ was transferred to a beaker to which $5 \mathrm{~mL}$ concentrated nitric acid was added and brought to a boil on a hot plate to the lowest volume possible (15 to $20 \mathrm{~mL}$ ). Filtration was done after digestion. The filtrate was then diluted to volume with distilled water in a $50 \mathrm{~mL}$ volumetric flask [11]. The concentration of heavy, alkali and alkaline metals were analysed using Atomic Absorption Spectrophotometer (AAS) by direct aspiration into a standardized computer interfaced Schimadzu AAS$6701 \mathrm{~F}$.

\subsection{Statistical Analysis}

The mean and standard deviation of the various parameters were calculated using analysis of variance (ANOVA) in excel windows. Pictorial representation of some parameters was also done to indicate comparison with local and International standards. Variations in concentration levels between the different locations were also observed.

\section{Results}

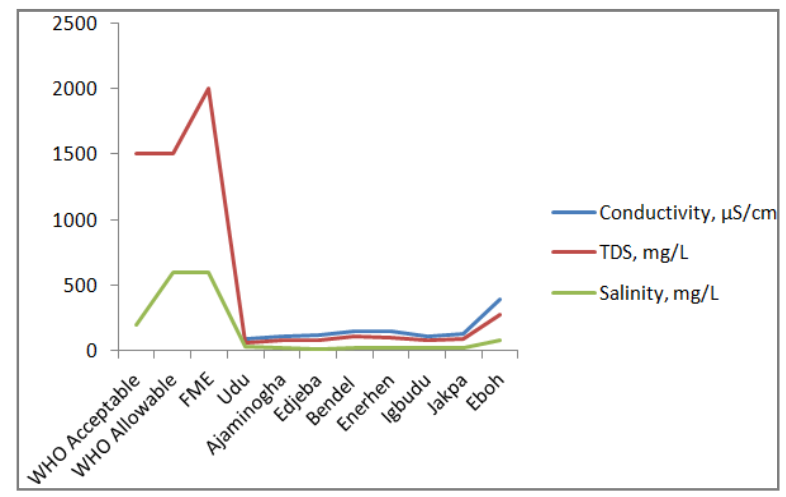

Fig 2. Mean concentration of salinity, TDS and conductivity levels in borehole water from Warri Metropolis
The results for twenty four (24) water samples analysed for potability in some areas in Warri, Delta State are presented Table 3. The water samples analyzed showed a short fall in $\mathrm{pH}$ when compared with local (Nigerian) and International (WHO) standards. Mean $\mathrm{pH}$ values were in the range of 4.15 (Edjeba) to 4.86 (Udu) $\mathrm{pH}$ units. Total dissolved solids (TDS) values were relatively low in most of the waters and were within acceptable limits $(61.33 \mathrm{mg} / \mathrm{L}-$ $277.0 \mathrm{mg} / \mathrm{L})$. All the waters sampled could be termed 'freshwater' as revealed in the salinity level, which ranged from $12.51 \mathrm{mg} / \mathrm{L}$ (Edjeba) to $82.59 \mathrm{mg} / \mathrm{L}$ (Eboh) (Figure 2). The mean turbidity values varied from 0.11 to 1.17 NTU. The waters were fairly soft as revealed in the results for total hardness $\left(12-16 \mathrm{mg} \mathrm{CaCO}_{3} / \mathrm{L}\right)$. The heavy metals analyzed in the different samples had concentrations that complied with acceptable International and Nigerian standards (Figure 3). However, values observed for iron, copper and zinc were in trace quantity. Lead, cadmium and chromium were not detected in any of the samples analyzed. The water samples from all the stations were free of microbial contamination.

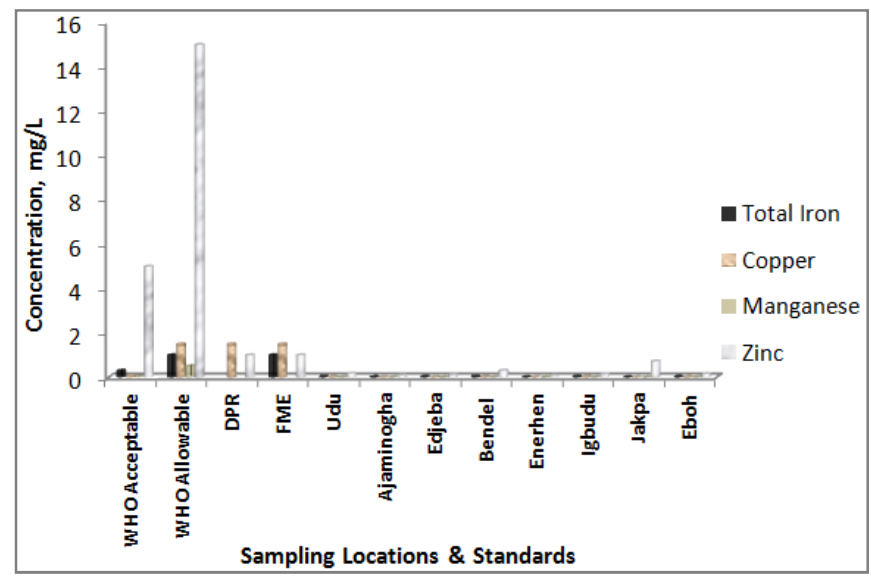

Fig 3. Mean concentration levels of heavy metals in borehole water from Warri Metropolis

Table 3. Values of Physico-chemical and biological parameters of groundwater samples in Warri Metropolis

\begin{tabular}{|c|c|c|c|c|c|c|}
\hline Parameters & $\begin{array}{l}\text { WHO Max } \\
\text { Acceptable limit }\end{array}$ & $\begin{array}{l}\text { WHO Max } \\
\text { Allowable limit }\end{array}$ & DPR Limit & FME Limit & Udu & Ajaminogha \\
\hline $\mathrm{pH}$ & $6.5-8.5$ & $6.5-9.2$ & $6.5-8.5$ & $6.5-8.5$ & $4.86 \pm 0.03$ & $4.43 \pm 0.04$ \\
\hline Temperature, ${ }^{\circ} \mathrm{C}$ & N/A & N/A & N/A & N/A & $28.9 \pm 0.08$ & $29.0 \pm 0.06$ \\
\hline Nitrate, $\mathrm{NO}_{3}-\mathrm{N}, \mathrm{mg} / \mathrm{L}$ & 10 & N/A & N/A & N/A & $0.04 \pm 0.01$ & $0.01 \pm 0.001$ \\
\hline Bicarbonate, $\mathrm{mg} \mathrm{CaCO}_{3} / \mathrm{L}$ & 500 & 500 & N/A & N/A & $4.88 \pm 0.01$ & $<0.01$ \\
\hline Sulphate, $\mathrm{mg} / \mathrm{L}$ & 200 & 400 & N/A & N/A & $1.05 \pm 0.001$ & $0.94 \pm 0.001$ \\
\hline Turbidity, NTU & 5 & 5 & N/A & 10 & $0.56 \pm 0.04$ & $0.14 \pm 0.01$ \\
\hline $\mathrm{TSS}, \mathrm{mg} / \mathrm{L}$ & N/A & N/A & N/A & N/A & $<1.00$ & $<1.00$ \\
\hline Hardness, $\mathrm{mg} \mathrm{CaCO}_{3} / \mathrm{L}$ & 500 & 500 & N/A & N/A & $16.0 \pm 0.3$ & $16.0 \pm 0.3$ \\
\hline Calcium, $\mathrm{mg} \mathrm{CaCO}_{3} / \mathrm{L}$ & 75 & 200 & N/A & N/A & $12.0 \pm 0.2$ & $12.0 \pm 0.2$ \\
\hline Magnesium, $\mathrm{mg} \mathrm{CaCO}_{3} / \mathrm{L}$ & 50 & 150 & N/A & N/A & $4.00 \pm 0.1$ & $4.00 \pm 0.1$ \\
\hline Total coliform, MPN/100 mL & Nil & Nil & N/A & N/A & Nil & Nil \\
\hline
\end{tabular}


Continued Table 3

\begin{tabular}{|c|c|c|c|c|c|c|}
\hline Parameters & Edjeba & Bendel Estate & Enerhen & Igbudu & Jakpa & Eboh \\
\hline $\mathrm{pH}$ & $4.15 \pm 0.05$ & $4.42 \pm 0.02$ & $4.38 \pm 0.04$ & $4.47 \pm 0.02$ & $4.69 \pm 0.06$ & $4.48 \pm 0.04$ \\
\hline Temperature, ${ }^{\circ} \mathrm{C}$ & $28.5 \pm 0.03$ & $29.5 \pm 0.03$ & $29.0 \pm 0.06$ & $30.0 \pm 0.06$ & $30.0 \pm 0.05$ & $30.0 \pm 0.05$ \\
\hline Nitrate, $\mathrm{NO}_{3}-\mathrm{N}, \mathrm{mg} / \mathrm{L}$ & $<0.01$ & $0.07 \pm 0.02$ & $0.33 \pm 0.05$ & $0.09 \pm 0.02$ & $0.15 \pm 0.04$ & $0.21 \pm 0.11$ \\
\hline Bicarbonate, $\mathrm{mg} \mathrm{CaCO}_{3} / \mathrm{L}$ & $<0.01$ & $<0.01$ & $<0.01$ & $<0.01$ & $3.66 \pm 0.01$ & $<0.01$ \\
\hline Sulphate, $\mathrm{mg} / \mathrm{L}$ & $0.75 \pm 0.001$ & $2.13 \pm 0.002$ & $2.98 \pm 0.002$ & $1.75 \pm 0.001$ & $2.43 \pm 0.002$ & $3.18 \pm 0.003$ \\
\hline Turbidity, NTU & $0.11 \pm 0.01$ & $0.26 \pm 0.01$ & $0.40 \pm 0.02$ & $0.88 \pm 0.04$ & $1.17 \pm 0.06$ & $0.37 \pm 0.04$ \\
\hline TSS, mg/L & $<1.00$ & $<1.00$ & $<1.00$ & $1.00 \pm 0.00$ & $1.00 \pm 0.00$ & $<1.00$ \\
\hline Calcium, $\mathrm{mg} \mathrm{CaCO}_{3} / \mathrm{L}$ & $8.00 \pm 0.1$ & $8.00 \pm 0.1$ & $8.00 \pm 0.1$ & $8.00 \pm 0.1$ & $12.0 \pm 0.2$ & $8.00 \pm 0.1$ \\
\hline Magnesium, $\mathrm{mg} \mathrm{CaCO}_{3} / \mathrm{L}$ & $4.00 \pm 0.1$ & $4.00 \pm 0.1$ & $4.00 \pm 0.1$ & $4.00 \pm 0.1$ & $4.00 \pm 0.1$ & $4.00 \pm 0.1$ \\
\hline Total coliform, MPN/100 mL & Nil & Nil & Nil & Nil & Nil & Nil \\
\hline
\end{tabular}

Values are means of 3 replicates

N/A $=$ Not available

TDS $=$ Total dissolved solids

\section{Discussion}

Water is a very vital resource and many nations strive to protect the safety of their water and to increase access to potable water [13]. Some countries have laws governing water safety, with severe penalties for polluters. In developed countries, people may not put a great deal of thought into the source of their water since their tap waters are enriched with fluoride for health $[2,14]$. However, in developing countries and particularly in Nigeria, a large population does not have access to safe water and relevant legislations are more concerned with industrial effluent / wastewater regulations rather than household water supplies / sources.

Potable water is essential and if our body is not continuously supplied with water, the body becomes dehydrated and vital organs would deteriorate until they are no longer viable for human life. However, according to researchers, not all organisms and contaminants found in drinking water are harmful as long as they do not exceed safety values established by the World Health Organization (WHO) [15].

In developed countries, the Local Governments, public water systems, the states, and regulators work together towards the goal of ensuring that all public water supplies are safe. Public water systems have a greater responsibility to maintain sound treatment works and water distribution networks. They are responsible for ensuring that the water they supply does not contain contaminants at levels higher than the law allows. However, in Nigeria, most if not all of these legislations are not duly followed and as such monitoring the quality of potable water is not done at any tier of government, leaving the citizens to drink any water available without proper water quality assessment. Since the Government no longer provides public water services, individuals resort to digging their own boreholes and these are not regulated or treated.

The results from this study indicated that the drinking waters were potable and parameters measured were within acceptable regulatory limits except the relatively low $\mathrm{pH}$ values obtained in all the waters. It has been known that intake of water with low $\mathrm{pH}$ values could cause some severe health implications including gastrointestinal disorder and ulcer.

At low levels, contaminants generally are not harmful in our drinking water. A few of the naturally occurring substances may actually improve the taste of drinking water and may have nutritional values at low levels. Therefore, contaminants should be removed when absolutely necessary. However, at high concentration, heavy metals could lead to certain disruption in both humans and organisms. It is also important to remember that removing contaminants does not secure increased safety of human health [1].

Slight variation was noted in some parameters in the locations sampled and could be attributed to the intensity of different activities and population in these areas. Udu has less industrial activities, while businesses and a high population are concentrated in Jakpa and Enerhen areas. Edjeba axis has more of industrial activities while Ajaminogha, Bendel Estate and Eboh are residential zones though few business activities. Igbudu has a large market and lot of waste activities. Although turbidity, total iron, copper, zinc showed slightly significant levels, only $\mathrm{pH}$ had values below the specified range for both local and International standard.

The results obtained could be due to activities in the areas which include: improper sanitary conditions, sewage or septic tanks in close distance to the boreholes, poor waste management practices, acid rain/precipitation, mechanic workshops - disposal of spent oil and grease and spent batteries amongst others. Any water may be safe to drink if it complies with certain regulatory standards for both physicochemical and microbial parameters. The guidelines / rules should be that values / concentrations should not exceed the required limits for it to be adjudged fit for human consumption.

\section{Conclusion}

Water is the essence of basic survival. Without it, life on Earth would cease to exist. In order to ensure that human life continues to exist, we must work together and do our part to improve the quality of drinking water. When the quality of drinking water is good, human health is also good. For the ground water samples covered in this assessment to be safe 
for drinking and other domestic use, they should be treated using the one or more of the following options: $\mathrm{pH}$ filters and lime to stabilize the $\mathrm{pH}$ while for low turbidity, the water should be passed through filter, which should be cleaned regularly. Similarly, in order to safe guard the health of humans; it is essential that the potable water be analyzed to ensure its integrity and / or standard before it is consumed. In addition, routine monitoring of drinking water should be carried out by individuals who are the consumers of such waters so as to detect any deviations from the set standards since the Government services are not functioning and cannot be relied upon.

\section{References}

[1] Gupta D.P., Sunita, J. and Saharan P., 2009. Physiochemical Analysis of groundwater of selected area of Kaithal City (Haryana) India. Researcher, 1(2): 1-5.

[2] Garg V.K., Chaudhary A., Deepshikha A. and Dahiya S., 1999. An appraisal of groundwater quality in some village of district Jind. Indian J Environ Prot. 19(4): 267-272.

[3] McGeer J.C., Brix K.V., Skeaff J.M., Deforest D.K. and Brigham S.I., 2003. Inverse relationship between bioconcentration factor and exposure concentration for metals: Implication for hazard assessment of metals in the aquatic environment. Environ. Toxicol. Chem., 22: 1017-1037.

[4] World Health Organization (WHO)., 2006. Guidelines for drinking water quality. $3^{\text {rd }}$ ed. WHO Press. Geneva, Switzerland. pp 398.

[5] Tawari-Fufeyin P. and Ekaye S.A., 2007. Fish species diversity as indicator of pollution in Ikpoba river, Benin City, Nigeria. Rev. Fish Biol. Fisheries., 17: 21-30.
[6] Riely, P.J. and Warren D.S., 1980. Money down the drain - A rational approach to sewage. The Ecologist 10:10.

[7] Federal Environmental Protection Agency (FEPA)., 1991. Guidelines and Standards for Environmental Pollution Control in Nigeria. University Press, Lagos. p. 238 - 245.

[8] Department of Petroleum Resources (DPR)., 2002. Environmental guidelines and standards for the petroleum industry in Nigeria (EGASPIN) Revised Edition. p. 277-288.

[9] Tamuno T., 2000. The Niger Delta question. Port Harcourt: Riverside Communications. Tell Magazine. (2005). 18 April, 16-18.

[10] Chinweze C. and Abiola-Oloke G., 2009. Women Issues, Poverty and Social Challenge of Climate Change in the Nigerian Niger Delta Context. Paper presented at the 7 th International Conference on the Human Dimension of Global Environmental Change (IHDP Open Meeting), UN Campus, Bonn, Germany; 26-30 April.

[11] American Public Health Association APHA, America Water Works Association. AWWA, Water Environmental Federation WEF., 2005. Standard methods for the examination of water and wastewater. $21^{\text {st }}$ ed.

[12] Folsom B.L., Lee C.R. and Bates D.J., 1981. Influence of disposal environment on availability and plant uptake of heavy metals in dredged material. Technol. Rep. EL-81-12.US Army Corps of Engineers Waterways Experiment Station, Vicksburg, MS.

[13] Routledge D. and Stewart D., 1998. Water: Essential for Existence. Explore Magazine. 8(5): 1-5.

[14] Shastri S.C., Bakra P.P. and Khan J.I., 1996. Industry environment and the law. R 13SA Publishers, Jaipur.

[15] Manivasakam N., 1996. Physical Chemical examination of water, sewage and industrial effluents 3rd ed, Pragati Prakashan, Meeret, India. 